\title{
IMPLEMENTASI MODEL PEMBELAJARAN KOOPERATIF TIPE STUDENT TEAMS ACHIEVEMENT DIVISIONS DALAM MENINGKATKAN HASIL BELAJAR IPS SISWA
}

\author{
Wina Dwi Puspitasari, M.Pd. \\ winad1211@gmail.com \\ Universitas Majalengka
}

\begin{abstract}
ABSTRAK
Penelitian ini dilatarbelakangi oleh masih kurangnya hasil belajar Ilmu Pengetahuan Sosial (IPS) siswa, atas dasar itulah tujuan penelitian ini untuk meningkatkan hasil belajar siswa pada mata pelajaran Ilmu Pengetahuan Sosial (IPS) di kelas IV SDN Majalengka Kulon I Kecamatan Majalengka Kabupaten Majalengka melalui penerapan model pembelajaran kooperatif tipe Student Teams Achievement Divisions. Penelitian ini merupakan penelitian tindakan kelas model Kemmis dan Mc. Taggart. Subjek penelitian adalah siswa kelas IV SDN Majalengka Kulon I Kecamatan Majalengka Kabupaten Majalengka sebanyak 20 siswa yang terdiri dari 10 siswa laki-laki dan 10 siswa perempuan. Teknik yang digunakan dalam pengumpulan data adalah tes, observasi dan dokumentasi. Data yang diperoleh berupa hasil tes sebagai data primer dan hasil observasi serta dokumentasi sebagai data pendukung. Teknik analisis data yang digunakan adalah teknik analisis deskripsi kuantitatif dan kualitatif. Penelitian dilaksanakan dalam 2 siklus yang masing-masing siklus terdiri dari satu tindakan. Hasil penelitian menunjukan bahwa penerapan model pembelajaran kooperatif tipe Student Teams Achievement Divisions (STAD) dapat meningkatkan hasil belajar siswa pada mata pelajaran IPS di kelas IV SDN Majalengka Kulon I Kecamatan Majalengka Kabupaten Majalengka. Hal ini ditunjukan dengan adanya peningkatan nilai sebelum diberikan tindakan hingga siklu II. Nilai rata-rata diperoleh sebelum tindakan mencapai 68,35 dengan persentase ketuntasan belajar sebesar 30\%. Pada siklus I rata-rata nilai mencapai 78,5 dengan persentase ketuntasan sebesar $65 \%$. Kemudian pada siklus II rata-rata nilai mencapai 87,25 dengan persentase ketuntasan $90 \%$. Berdasarkan data tersebut dapat disimpulkan bahwa penerapan model pembelajaran kooperatif tipe Student Teams Achievement Divisions (STAD) dapat meningkatkan hasil belajar IPS pada kelas IV SDN Majalengka Kulon I Kecamatan Majalengka Kabupaten Majalengka Tahun Ajaran 2017-2018.
\end{abstract}

Kata Kunci: Hasil Belajar Siswa, Pembelajaran IPS, Model Kooperatif tipe Student Teams Achievement Divisions 


\section{Pendahuluan}

Ilmu Pengetahuan Sosial merupakan ilmu-ilmu yang memusatkan perhatiannya tentang kehidupan dan tingkah laku manusia serta kebutuhannya. Konsep IPS yang dipelajari oleh siswa merupakan keragaman dari berbagai fenomena yang ada dalam kehidupan sehari-hari. Dengan mempelajari IPS siswa belajar tentang kehidupan sosial diantaranya kepekaan terhadap suatu masalah sosial yang terjadi di lingkungannya.

Bahan kajian Ilmu Pengetahuan

Sosial (IPS) dimaksudkan untuk mempelajari dan menelaah serta menganalisis gejala dan masalah sosial di masyarakat ditinjau dari berbagai aspek kehidupan secara terpadu. IPS tidak akan pernah lepas dari kehidupan, karena di dalamnya membahas tentang gejala dan masalah sosial di masyarakat yang ditinjau dari berbagai aspek kehidupan sosial.

Penekanan pembelajaran IPS bukan sebatas pada upaya membekali peserta didik dengan sejumlah konsep yang bersifat hapalan melainkan terletak pada upaya agar mereka mampu menjadikan apa yang telah dipelajarinya sebagai bekal dalam memahami dan ikut serta dalam menjalani kehidupan di masyarakat, serta sebagai bekal bagi siswa untuk melanjutkan jenjang pendidikan selanjutnya. Namun sayangnya, banyak guru berpendapat bahwa mengajar IPS tidak semudah seperti yang dibayangkan karena materi pembelajaran IPS mengkaji mengenai kehidupan sosial. Bukan hanya mesti dipahami tetapi juga bisa diaplikasikan. Karena kendala tersebut pada akhirnya banyak guru yang hanya menanamkan pembelajaran IPS secara konseptual bukan aplikatif. Hal ini berimbas pada rendahnya hasil belajar siswa.

Hal serupa dialami oleh siswa kelas IV SDN Majalengka Kulon I Kecamatan Majalengka Kabupaten
Majalengka. Berdasarkan hasil observasi pada mata pelajaran IPS diperoleh hasil belajar masih banyak siswa yang belum tuntas sesuai dengan Kriteria Ketuntasan Minimal (KKM) yaitu 75. Hal ini dibuktikan dengan kurangnya antusias siswa terhadap proses pembelajaran, siswa cenderung melakukan aktivitas lain yang dapat mengganggu proses pembelajaran, tidak adanya kesiapan siswa ketika akan memulai pembelajaran, dan pembelajaran yang kurang menyenangkan sehingga membuat siswa kurang terlibat aktif dalam pembelajaran.

Pembelajaran IPS tidak dapat berhasil dengan pembelajaran konvensional saja, akan tetapi harus bisa membuat siswa ikut terlibat aktif dalam pembelajarannya sehingga dapat membangun rasa ingin tahu siswa dan keterampilan siswa. Dengan demikian pembelajaran IPS menjadi menyenangkan dan merasa perlu untuk dipelajari. Maka dari itu untuk menciptakan pembelajaran dan hasil belajar yang baik tentunya diperlukan penerapan sebuah metode, strategi atau model pembelajaran yang sesuai dan mampu menciptakan suasana kelas yang aktif, efektif, dan menyenangkan dalam pembelajaran. Model yang dianggap paling sesuai dengan pembelajaran IPS yakni pembelajaran kooperatif tipe Student Teams Achievement Divisions (STAD).

Menurut Slavin (Rusman, 2016:

214) menyatakan bahwa model cooperative Learning tipe Student Teams Achievement Divisions merupakan model yang dapat menumbuhkan sikap saling membantu, memotivasi antara peserta didik dengan peserta didik lainnya dalam belajar, terutama dalam menguasai materi ajar yang disampaikan guru. Dalam hal ini siswa ditempatkan dalam kelompok belajar beranggotakan empat atau lima yang merupakan campuran dari beragam latar belakang peserta didik baik dari segi karakteristik, jenis kelamin, kelompok ras, 
etnis dan kelompok sosial lainnya serta kemampuan akademik yang berbeda-beda dari setiap siswa sehingga dalam setiap kelompok terdapat siswa yang berprestasi tinggi, sedang, dan rendah. Dengan demikian dapat memacu siswa agar saling membantu satu sama lain terkait keterampilan yang diajarkan guru.

Menurut Rusman (2016: 202) mendefinisikan pembelajaran kooperatif sebagai berikut: Pembelajaran kooperatif (cooperative learning) merupakan bentuk pembelajaran dengan cara siswa belajar dan bekerja dalam kelompok-kelompok kecil secara kolaboratif dan anggotanya terdiri dari empat sampai enam orang dengan struktur kelompok yang bersifat heterogen. Berdasarkan definisi tersebut dapat disimpulkan bahwa melalui pembelajaran kooperaif tersebut siswa dapat aktif, kreatif dan mampu memunculkan ide-ide dalam proses belajar dan dapat memupuk rasa saling membantu antar siswa dalam kelompok. Pembelajaran kooperatif dapat membuat siswa menjadi lebih mudah dalam menemukan dan memahami suatu konsep atau materi yang disampaikan guru jika dilakukan dengan saling berdiskusi dengan teman yang lain

\section{Metode dan Desain Penelitian}

Penelitian ini dilakukan di kelas IV SDN Majalengka Kulon I Kecamatan Majalengka Kabupaten Majalengka Tahun ajaran 2017-2018. Dalam penelitian ini lebih terfokus pada mata pelajaran Ilmu Pengetahuan Sosial (IPS). Penelitian ini dilakukan karena atas dasar ditemukannya permasalahan dari hasil observasi.

Jenis penelitian yang akan dilakukan peneliti adalah Penelitian Tindakan Kelas (PTK). Kemmis (Sanjaya 2015: 24) menjelaskan bahwa: penelitian tindakan adalah suatu bentuk penelitian reflektif dan kolektif yang dilakukan oleh peneliti dalam situasi sosial untuk meningkatkan penalaran praktik sosial mereka.

Sementara menurut Sanjaya (2015: 26) mendefinisikan yaitu sebagai berikut: PTK dapat diartikan sebagai proses pengkajiaan masalah pembelajaran di dalam kelas melalui refleksi diri dalam upaya untuk memecahkan masalah tersebut dengan cara melakukan berbagai tindakan yang terencana dalam situasi nyata serta menganalisis setiap pengaruh dari perlakuan tersebut.

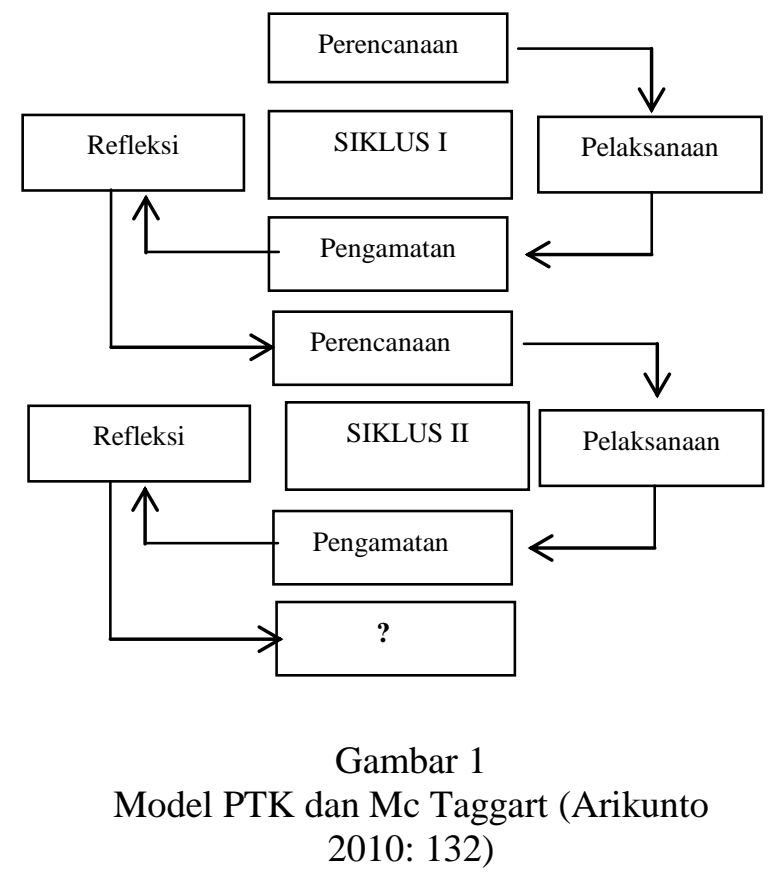

Hasil belajar diukur dengan menggunakan teknik tes dan observasi. Tes digunakan untuk mengukur kognitif sementara observasi digunakan untuk mengukur afektif dan psikomotor.

\section{Hasil Penelitian dan Pembahasan}

Penelitian yang dilaksanakan di kelas IV SDN Majalengka Kulon I Kecamatan Majalengka Kabupaten Majalengka ini berdasarkan pada permasalahan atau fenomena yang terjadi, kemudian disusun rumusan masalah sebagai acuan, sebagaimana telah dirumuskan pada bab I. Dari hasil penelitian, khususnya hasil pengamatan yang dilakukan peneliti sebelum dilakukan 
tindakan, diperoleh data awal yang menyatakan bahwa hasil pelaksanaan pembelajaran IPS belum optimal, berdasarkan data yang diperoleh hasil belajar pada mata pelajaran IPS masih banyak siswa yang belum tuntas sesuai dengan Kriteria Ketuntasan Minimal (KKM) yaitu 75. Hal ini dibuktikan dengan kurangnya antusias siswa terhadap proses pembelajaran, siswa cenderung melakukan aktivitas lain yang dapat mengganggu proses pembelajaran, dan pembelajaran yang kurang menyenangkan karena kebiasaan guru yang mentransfer pengetahuannya hanya dengan metode ceramah dengan kata lain minimnya kreativitas dalam mengemas pembelajaran IPS sehingga membuat siswa kurang terlibat aktif dalam proses pembelajaran dan hasil belajar yang di dapat para siswa masih rendah.

Berdasarkan hasil kegiatan pembelajaran melalui penerapan model pembelajaran kooperatif tipe Student Teams Achievement Divisions (STAD) yang telah dilaksanakan dengan dua siklus, diperoleh hasil dari penerapan model pembelajaran kooperatif tipe Student Teams Achievement Divisions (STAD) yang menunjukan adanya peningkatan dan tentunya bahwa penerapan model tersebut dapat dilaksanakan dengan optimal melalui perbaikan pada setiap siklusnya. Adapun untuk lebih jelasnya terkait pembahasan penelitian ini adalah sebagai berikut:

\section{Penerapan Model Pembelajaran Kooperatif tipe Student Team Achievement Divisions}

Proses pembelajaran IPS yang dilaksanakan di kelas IV SDN Majalengka Kulon I Kecamatan Majalengka Kabupaten Majalengka dengan menggunakan model pembelajaran kooperatif tipe Student Teams Achievement Divisions (STAD) dilakukan sesuai dengan langkah pembelajaran pada model ini. Sebagaimana menurut Rusman
(2016: 215-217) bahwa langkah model STAD ini mulai dari penyampaian tujuan dan memotivasi, presentase guru, pembagian kelompok, kerja tim, pemberian kuis/evaluasi dan terakhir penghargaan team.

Berdasarkan observasi kegiatan guru selama proses pembelajaran dari siklus ke siklus persentasenya mengalami peningkatan. Adapaun rekapitulasi keterlaksanaan pembelajaran yang dilaksanakan guru dari siklus I ke siklus II adalah sebagai berikut:

Tabel 1

Rekapitulasi Hasil Observasi Guru

\begin{tabular}{|c|c|c|c|}
\hline No. & Siklus & Persentase & Kategori \\
\hline 1 & Siklus I & $68,75 \%$ & Cukup \\
\hline 2 & Siklus II & $87,5 \%$ & Baik Sekali \\
\hline
\end{tabular}

Pengamatan guru pada siklus I terdapat temuan esensial yang didapat dari hasil catatan lapangan dalam pelaksanaan pembelajaran; pembelajaran kurang kondusif, siswa kurang terlibat aktif dan masih terdapat siswa yang kurang paham terhadap materi yang disampaikan oleh guru, hal ini disebabkan oleh guru (peneliti) belum dapat menggunakan waktu dengan efektif dan efisien dalam kegiatan pembelajaran, yakni ditandai dengan kegiatan pembelajaran yang melebihi alokasi waktu yang telah ditentukan. Hal itu dapat dilihat dari data/hasil pengamatan guru yang dilakukan pada pelaksanaan pembelajaran yaitu secara keseluruhan keterlaksanaan pembelajaran yang dilakukan guru dengan presentase $68,75 \%$. Sedangkan pada siklus II kekurangan atau kendala yang ditemui diperbaiki sehingga secara keseluruhan keterlaksanaan pembelajaran yang dilakukan guru dengan presentase 87,5\%.

Adapaun peningkatan persentase keterlaksanaan pembelajaran yang dilaksanakan guru dari siklus I ke siklus II dapat dilihat pada grafik di bawah ini: 


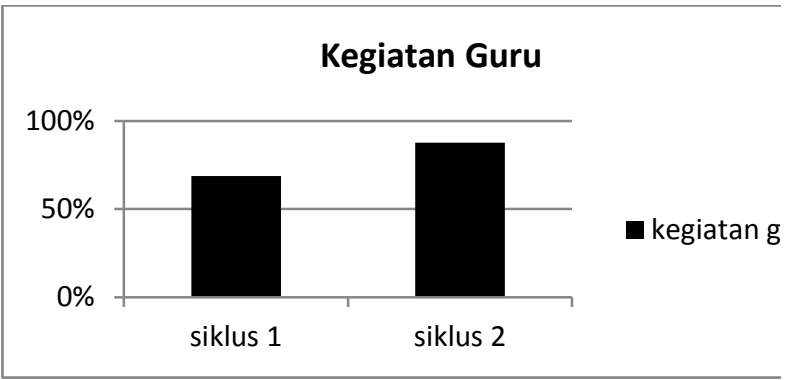

Gambar 2

Grafik Hasil Observasi Guru

Berdasarkan grafik di atas, dapat diketahui bahwa terjadinya peningkatan persentase keterlaksanaan pembelajaran pada lembar observasi guru melalui penerapan model pembelajaran kooperatif tipe Student Teams Achievement Divisions. Pada lembar observasi guru dari hasil siklus I yang mendapat 68,75\% mengalami peningkatan pada siklus II menjadi $87,5 \%$.

Berdasarkan hasil pengamatan pada kegiatan pembelajaran tersebut, khususnya pembelajaran IPS bahwa dalam hal ini siswa dilibatkan secara langsung di dalamnya dengan memotivasi, mengikutsertakan siswa secara aktif berpartisipasi dalam kelompok yang heterogen untuk bertukar pendapat guna memecahakan permasalahan terkait materi yang diberikan oleh guru. Hal ini selaras dengan teori Jarolimek (Susanto, 2014: 9) menyatakan bahwa IPS merupakan ilmu pengetahuan yang memberikan kemampuan kepada anak didik dalam mengelola dan memanfaatkan kekuataankekuatan fisik dan sosial dalam menciptakan kehidupan yang serasi juga mempersiapkan anak didik untuk mampu memecahkan masalah sosial dan memiliki keyakinan akan kehidupan masa mendatang.

Observasi kegiatan siswa selama proses pembelajaran dari siklus ke siklus persentasenya juga mengalami peningkatan. Adapaun rekapitulasi keterlaksanaan pembelajaran yang dilaksanakan siswa dari siklus I ke siklus II adalah sebagai berikut:

Tabel 2

Rekapitulasi Hasil Observasi Siswa

\begin{tabular}{|l|c|c|c|}
\hline No. & Siklus & Persentase & Kategori \\
\hline 1 & Siklus I & $70,83 \%$ & Baik \\
\hline 2 & Siklus II & $83,33 \%$ & Baik Sekali \\
\hline
\end{tabular}

Pengamatan siswa pada siklus I terdapat temuan esensial yang didapat dari hasil catatan lapangan dalam pelaksanaan pembelajaran; siswa masih cenderung melakukan hal-hal yang mengganggu terhadap proses pembelajaran berlangsung (bercanda dengan temannya), siswa kurang terlibat aktif sehingga siswa kurang memahami materi yang disampaikan guru sehingga pada siklus I secara keseluruhan keterlaksanaan pembelajaran yang dilakukan siswa dengan persentase sebesar 70,83\% Kemudian, setelah dilakukan perbaikan mengenai berbagai kendala atau kekurangan yang ditemui pada siklus I, pada siklus II mengalami peningkatan yaitu secara keseluruhan keterlaksanaan pembelajaran yang dilakukan siswa sebesar $83,33 \%$.

Adapaun peningkatan persentase keterlaksanaan pembelajaran yang dilaksanakan siswa dari siklus I ke siklus II dapat dilihat pada grafik di bawah ini:

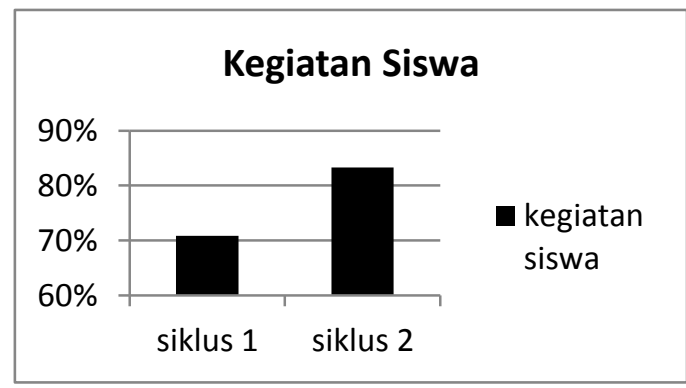

Gambar 3

Grafik Hasil Observasi Siswa

Berdasarkan grafik di atas, dapat di ketahui bahwa terjadinya peningkatan persentase keterlaksanaan pembelajaran 
pada lembar observasi guru melalui penerapan model pembelajaran kooperatif tipe Student Teams Achievement Divisions (STAD). Pada lembar observasi guru dari hasil siklus I yang mendapat 70,83\% mengalami peningkatan pada siklus II menjadi 83,33.

2. Hasil Belajar Siswa dengan Penerapan Model Pembelajaran Kooperatif tipe Student Team Achievement Divisions (STAD)

Penerapan model pembelajaran kooperatif tipe Student Teams Achievement Divisions (STAD) dapat membuat pengalaman belajar tidak sekedar ceramah atau berpusat pada guru. Akan tetapi dalam kegiatan pembelajarannya siswa diarahkan untuk belajar dalam kelompok membangun kerja tim dengan saling membantu dan memotivasi dalam belajar guna dapat memahami persoalan yang berikan oleh guru untuk dapat dipahami dan di pecahkan sehingga kegiatan pembelajaran menjadi lebih baik. Hal ini selaras dengan teori Slavin (Rusman, 2016: 214) memaparkan bahwa 'model Student Teams Achievement Divisions (STAD) merupakan model yang dapat memacu siswa agar saling mendorong dan membantu satu sama lain untuk menguasai keterampilan yang diajarkan guru'.

Sebelum melaksanakan tindakan, data kondisi awal hasil belajar siswa kelas IV SDN Sukaperna II yaitu rata-rata nilai sebesar 68,35 dengan persentase ketuntasan klasikal sebesar 30\%. Hal ini dikarenakan metode yang digunakan pada saat kegiatan pembelajaran masih berpusat pada guru, pembelajaran seperti ini menjadikan siswa kurang terlibat aktif dalam pembelajaran sehingga hasil belajar yang diperoleh pun masih belum optimal. Teori yang dikutip oleh peneliti, Arifin (2014: 298) mengemukakan bahwa hasil belajar adalah hasil dari suatu interaksi tindak belajar dan tindak mengajar.
Berdasarkan teori tersebut pembelajaran yang hanya berpusat pada guru tidak akan mencapai hasil belajar yang optimal dikarenakan pengalaman belajarnya hanya dari penjelasan guru dengan kata lain tidak ada pengalaman yang lebih membuat siswa paham guna mencapai hasil belajar yang optimal, karena dalam hal ini harus adanya suatu interaksi dengan melibatkan siswa aktif dalam pembelajaran guna mencapai hasil belajar yang optimal. Tes hasil belajar siswa dilakukan sebanyak 2 siklus yang masing-masing siklus terdiri dari 1 tindakan. Hasil tes pada setiap tindakan mengalami perbaikan. Berikut adalah rekapitulasi hasil belajar siswa pada dan setelah menggunakan model pembelajaran kooperatif tipe Student Teams Achievement Divisions:

Tabel 3

Rekapitulasi Hasil Belajar

\begin{tabular}{|l|c|c|c|c|c|}
\hline \multicolumn{1}{|c|}{ Ket } & $\begin{array}{c}\text { Pra } \\
\text { Siklus }\end{array}$ & \multicolumn{2}{c|}{ Tindakan } & \multicolumn{2}{c|}{ Peningkatan } \\
\cline { 3 - 6 } & $\begin{array}{c}\text { Siklus } \\
\text { I }\end{array}$ & Siklus IIPra Siklus & $\begin{array}{c}\text { Siklus I ke } \\
\text { ke Siklus I }\end{array}$ & Siklus II \\
\hline $\begin{array}{l}\text { Nilai Rata- } \\
\text { rata }\end{array}$ & 68,35 & 78,5 & 87,25 & 10,15 & 8,75 \\
\hline $\begin{array}{l}\text { Presentase } \\
\text { Ketuntasan }\end{array}$ & $30 \%$ & $65 \%$ & $90 \%$ & $35 \%$ & $25 \%$ \\
\hline $\begin{array}{l}\text { Jumlah } \\
\text { siswa tuntas }\end{array}$ & 6 & 13 & 18 & & \\
\hline
\end{tabular}

Berdasarkan data pada tabel di atas, dapat terlihat bahwa penerapan model pembelajaran kooperatif tipe Student Teams Achievement Divisions mengalami peningkatan.

Tes hasil belajar diberikan pada setiap akhir pembelajaran siklus I dan siklus II. Dari data yang diperoleh bahwa hasil tes mengalami peningkatan. Pada kondisi awal hasil belajar siswa hanya diperoleh nilai rata-rata sebesar 68,35 dengan persentase ketuntasan sebesar $30 \%$. Setelah dilakukannya tindakan pada siklus I hasil tes belajar siswa mengalami peningkatan dengan nilai rata-rata sebesar 78,5 dengan persentase ketuntasan sebesar $65 \%$. Dalam hal ini terlihat bahwa hasil belajar setelah peneliti menerapkan model pembelajaran kooperatif tipe Student 
Teams Achievement Divisions mengalami peningkatan, namun belum sampai pada kriteria yang ditentukan.

Menurut Sudjana (2014: 33) menjelaskan bahwa jika hasil belajar siswa (kelas) belum mencapai tujuan dengan kriteria $80 \%$ dari target yang diharapkan, berarti pengajaran itu gagal dan harus di ulangi kembali (re-teaching atau mengajar kembali). Hal ini dikarenakan adanya kekurangan dan hambatan pada pelaksanaan kegiatan pembelajaran terkait lembar observasi guru dan lembar observasi siswa.

Pada tahap refleksi dilakukan perbaikan mengenai berbagai kendala atau kekurangan yang ditemui pada siklus I, tes hasil belajar pada siklus II Mengalami peningkatan yaitu dengan nilai rata-rata sebesar 87,25 dengan persentase ketuntasan 90\%. Dari 20 orang siswa hanya 2 orang yang tidak mencapai ketuntasan KKM, hal ini dikarenakan faktor belajar siswa kurang terlibat aktif pada saat pembelajaran dan nilai tesnya yang tidak memenuhi serta siswa tersebut memang lambat dalam belajar. Namun dalam hal ini dikarenakan persentase sudah melebihi hasil yang ditetapkan maka berdasarkan hasil tersebut penelitian ini dihentikan pada siklus II.

Adapaun peningkatan nilai rata-rata dan ketuntasan hasil belajar siswa dapat digambarkan dengan grafik di bawah ini:

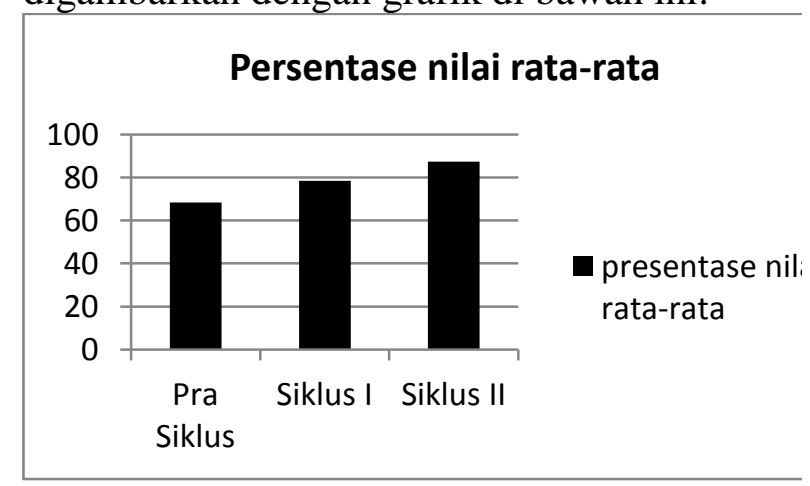

Gambar 4

Grafik Nilai Rata-Rata Siswa

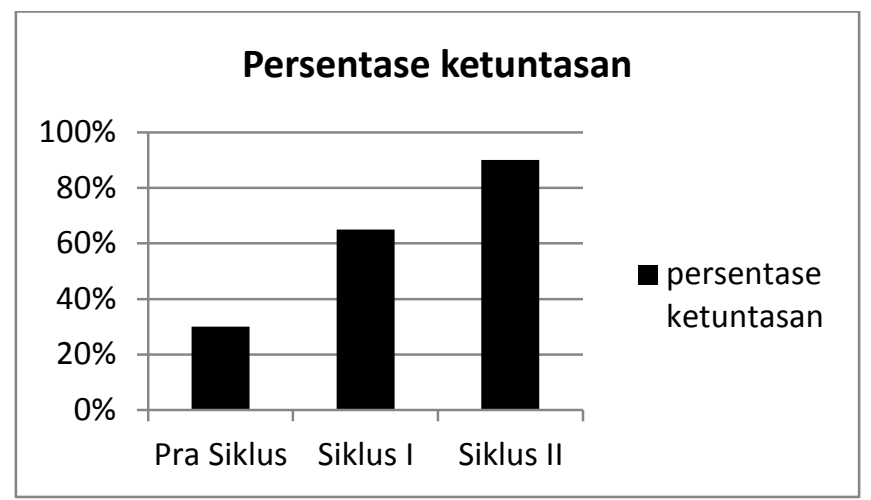

Grafik Ketuntasan Belajar Siswa

3. Peningkatan Hasil Belajar Siswa setelah Menggunakan Model Pembelajaran Kooperatif tipe Student Team Achievement Divisions

Dari penelitian tindakan kelas yang telah dilakukan oleh peneliti di SDN Majalengka Kulon I Kecamatan Majalengka Kabupaten Majalengka dengan menerapkan model pembelajaran kooperatif tipe Student Teams Achievement Divisions (STAD) bahwa perbandingan hasil belajar siswa menunjukan adanya peningkatan. Terjadinya peningkatan ini tentu bertemali dengan kelebihan dari model pembelajaran kooperatif tipe Student Teams Achievement Divisions, menurut Ahmadi (2011: 65) mengemukakan kelebihan dari model STAD bahwa menggalakan interaksi secara aktif dan positif dan kerjasama anggota kelompok menjadi lebih baik. Kemudian menurut Isjoni (2010: 72) menyatakan kelebihan dari model STAD bahwa melatih siswa dalam mengembangkan aspek kecakapan sosial di samping kecakapaan kognitif. Dengan demikian dapat dikatakan bahwa model STAD mampu meningkatkan hasil belajar siswa. Peningkatan tersebut pula dapat dilihat dari kondisi awal/pra siklus nilai rata-rata siswa yaitu 68,35 dan setelah melakukan tindakan pada siklus I nilai rata-rata siswa meningkat menjadi 78,5 hal tersebut menunjukan terjadi peningkatan mencapai 10,15 . Sedangkan dari siklus I ke siklus II nilai rata-rata 
siswa yang didapat yaitu 87,25 hal ini menunjukan terdapat peningkatan kembali mencapai 8,75.

Peningkatan hasil belajar siswa dapat dilihat dari persentase ketuntasan hasil belajar bahwa dari kondisi awal/pra siklus yaitu dengan persentase sebesar $30 \%$ dan setelah melakukan tindakan pada siklus I ketuntasan hasil belajar siswa mengalami peningkatan menjadi $65 \%$, hal tersebut menunjukan bahwa terjadinya peningkatan sebesar $35 \%$. Kemudian peneliti melakukan perbaikan pada siklus II, persentase yang didapat sebesar $90 \%$ hal ini menunjukan terdapat peningkatan kembali dari siklus I menuju siklus II sebesar $25 \%$.

Peningkatan hasil belajar siswa dari kondisi awal ke siklus I menunjukan peningkatan yang signifikan. Hal tersebut tentu dikarenakan adanya perbedaan dari kondisi awal dengan siklus I, jika pada kondisi awal proses pembelajarannya hanya berpusat pada guru atau pembelajaran dengan metode ceramah sedangkan pada siklus I dan siklus II peneliti menggunakan atau menerapakan model pembelajaran kooperatif tipe Student Teams Achievement Divisions sebagai model pembelajaran.

Model pembelajaran kooperatif tipe Student Teams Achievement Divisions berhasil meningkatkan hasil belajar siswa, namun dalam proses pembelajarannya tidak dapat dipungkiri adanya kendala atau kekurangan yang ditemui, terlepas dari hal tersebut peneliti melakukan perbaikan sehingga pada siklus II mencapai ketuntasan yang ditetapkan sebesar $80 \%$ dan peneliti menghentikan penelitian ini pada siklus II.

\section{Simpulan}

Berdasarkan hasil penelitian dapat ditarik kesimpulan bahwa penerapan model pembelajaran kooperatif tipe Student Teams Achievement Divisions dapat meningkatkan hasil belajar siswa di kelas IV pada pembelajaran IPS, hal tersebut dibuktikan dengan adanya peningkatan hasil belajar pada setiap siklusnya.

\section{Daftar Pustaka}

Ahamdi, I.K, dkk. (2011). Strategi Pembelajaran Sekolah Terpadu "Pengaruhnya Terhadap Konsep, Mekanisme, dan Proses Pembelajaran Sekolah Swasta dan Negeri". Jakarta: PT. Prestasi Pustakaraya.

Arifin, Z., dkk. (2014). Penelitian Tindakan Kelas untuk Guru SD, $S L B, T K$. Bandung: Yrama Widya.

Arikunto, S. (2010). Penelitian Tindakan Kelas. Jakarta: PT. Bumi Aksara.

Isjoni. (2010). Cooperative Learning Efektifitas Pembelajaran Kelompok. Bandung: Alfabeta.

Rusman. (2016). Model-model pembelajaran. Jakarta: PT. Raja Grafido Persada.

Sanjaya, W. (2015). Penelitian Tindakan Kelas. Jakarta: Pernadamedia Group.

Sudjana, N. (2013). Tuntunan penyusunan karya ilmiah. Bandung: Sinar Baru Algansindo.
Susanto, A. (2014). Pengembangan Pembelajaran IPS. Jakarta: Prenadamedia Group..

